\title{
New Roles for Glia
}

\author{
Barbara A. Barres \\ Department of Biology, University College London, London WC1E 6BT, England
}

Recent findings suggest that glial cells, though lacking the excitability usually associated with most neurons, may be more actively involved in brain function than has been previously thought. Collectively, these findings indicate that glial cells can sense, and potentially respond to, a large array of neuronal signals. Because glial cells are intimately associated with most neurons, neurobiologists should reconsider the possible significance of active neuronal-glial signaling.

\section{Ion channels of glial cells}

New studies, made possible with patch-clamp recording, have shown that glial cells in vitro and in situ possess most of the same kinds of voltage-dependent ion channels that are found in neurons (reviewed in Barres et al., 1990a; Bevan, 1990). These findings were unexpected because earlier microelectrode recordings indicated that voltage-dependent conductances were not present in glial cells. These differences in findings are probably attributable to the different techniques used: the patchclamp studies generally have been performed on isolated single cells, whereas the microelectrode recordings tended to be performed on cells in vitro and in situ that were highly coupled in a glial syncytium, which tends to obscure the presence of the voltage-dependent channels (for further discussion, see Barres et al., 1990a). The horizontal neurons in the retina, which are also extensively coupled in situ, were similarly long thought to be lacking voltage-dependent conductances.

Although a variety of glial preparations have been studied, the basic findings are common and are exemplified by studies of rat optic nerve glia (Barres et al., 1988a, 1990b,c). Cultures of cells isolated from postnatal optic nerves contain four types of macroglial cells that can be distinguished by their distinct antigenic phenotypes and morphologies: type 1 astrocytes, type 2 astrocytes, oligodendrocytes, and a progenitor cell, termed the O2A progenitor (Raff et al., 1983a; Miller and Raff, 1984; reviewed in Miller et al., 1989a). The O2A progenitors are developmentally bipotential, giving rise to both oligodendrocytes and type 2 astrocytes in vitro (Raff et al., 1983b, 1984). O2A progenitors persist in adult animals (ffrench-Constant and Raff, 1986; Wolswijk and Noble, 1989) in large numbers (B. Fulton,

Correspondence should be addressed to Barbara A. Barres, Department of Biology, University College London, Medawar Building B3, Gower Street, London WC1E 6BT, UK.

Copyright (C) 1991 Society for Neuroscience $0270-6474 / 91 / 113685-10 \$ 05.00 / 0$
J. Burne, and M. Raff, unpublished observations). These cell types are not thought to comprise all kinds of CNS glia; rather, they may be restricted to the kinds of glia present in white matter. As shown in Table 1, each optic nerve glial cell type also expresses a characteristic set of voltage-dependent ion channel types in vitro.

In vivo, glial cells also possess characteristic ion channel phenotypes. For instance, if cells are studied immediately after preparation using a "tissue print" dissociation procedure, voltage-dependent channels are observed in all rat optic nerve glia (Barres et al., 1990c). Tissue prints are prepared by gently blotting a small piece of enzymatically treated tissue against a sticky nontoxic surface such as nitrocellulose-coated glass. This yields a thin layer of viable optic nerve cells still bearing processes. Because the enzymes used to isolate the cells in this procedure do not digest any of the basic ion channel types and leave the cells with much of their surface area in the form of processes intact, the observed types of ion channels probably reflect the in situ properties. As is true in vitro, each optic nerve glial cell type studied in such tissue prints displays a distinct ion channel phenotype (Table 1).

Voltage-dependent $\mathrm{Na}^{+}$and $\mathrm{Ca}^{2+}$ channels, which are traditionally associated with excitability and neurotransmitter release, are frequently observed in acute glial preparations. For instance, $\mathrm{Na}^{+}$channels are ubiquitously prescnt in astrocytes in situ. An estimate of how densely packed these ion channels are in the membrane can be calculated by dividing the peak conductance by the cell surface area (surface area is generally determined by measuring the cell's capacitance in picofarads). In general, the densities of $\mathrm{K}^{+}$channels in glial cells are similar to those of neurons, while the densities of $\mathrm{Na}^{+}$channels and $\mathrm{Ca}^{2+}$ channels in glia are considerably lower than those of neurons. An exception is the $\mathrm{O} 2 \mathrm{~A}$ progenitor cell, which has a density of $\mathrm{Na}^{+}$channels that approaches that found in neurons (Barres et al., 1990b).

The properties of glial ion channels can differ from those of neurons. $\mathrm{Na}^{+}$channels in type 1 astrocytes, for example, open at more negative potentials and open more slowly than $\mathrm{Na}^{+}$ channels in neurons in response to depolarization (Table 2; Barres et al., 1989). Their more negative voltage dependence suggests that the glial $\mathrm{Na}^{+}$channcls are specialized to detect the more negative membrane potential that is found in glia. Surprisingly, only the neuronal form of the $\mathrm{Na}^{+}$channel is found in $\mathrm{O} 2 \mathrm{~A}$ progenitor cells (Table 2). An unresolved question is 
Table 1. Types of voltage-dependent ion channels found in rat optic nerve glia

\begin{tabular}{|c|c|c|c|c|c|c|c|c|}
\hline & Type 1 a & cytes & $\begin{array}{l}\text { Type } 2 \\
\text { astrocyles }\end{array}$ & O2A pro & tors & Oligoden & cytes & $\begin{array}{l}\text { Retinal } \\
\text { ganglion } \\
\text { cells }\end{array}$ \\
\hline & Culture & Print & Culture & Culture & Print & Culture & Print & Suspension \\
\hline $\mathrm{K}_{\mathrm{IR}}$ & - & + & + & - & - & + & + & - \\
\hline $\mathrm{K}_{D}$ & + & + & + & + & + & + & + & + \\
\hline $\mathrm{K}_{A}$ & - & - & + & + & + & + & + & + \\
\hline $\mathrm{Na}_{G}$ & - & + & + & - & - & - & - & - \\
\hline $\mathrm{Na}_{N}$ & - & - & + & + & + & - & - & + \\
\hline $\mathrm{Ca}_{T}$ & - & + & + & - & - & - & - & + \\
\hline $\mathrm{Ca}_{L}$ & - & + & + & - & - & - & - & + \\
\hline
\end{tabular}

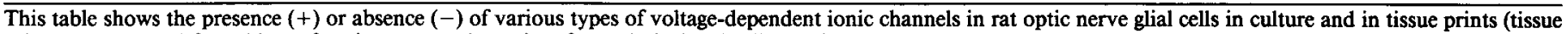

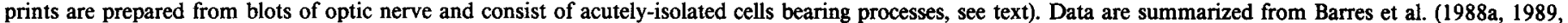

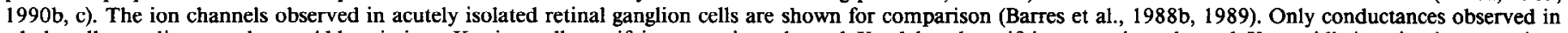

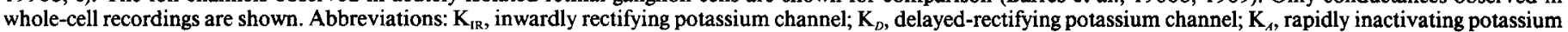

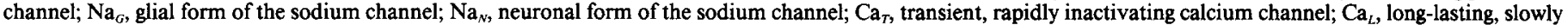
inactivating calcium channel. Very minor current components, or current components found in only a small subset of cells, are not shown.

whether the glial and neuronal forms of the $\mathrm{Na}^{+}$channel are different proteins.

Despite the presence of $\mathrm{Na}^{+}$channels, the high resting conductance of most glial cell types in vitro and in situ appears to exclude any robust excitability, although single regenerative potentials can sometimes be elicited under experimental conditions where the resting potassium conductance is diminished. [It is possible, however, that the $\mathrm{O} 2 \mathrm{~A}$ progenitors are excitable in vivo, as they have a low resting conductance in addition to their high density of $\mathrm{Na}^{+}$channels (Barres et al., 1989; 1990b).] The lack of astrocyte and Schwann cell excitability has led Ritchie and his colleagues to hypothesize that glial cells might synthesize $\mathrm{Na}^{+}$channel proteins for transfer to neurons (Bevan et al., 1985). That $\mathrm{Na}^{+}$channels are thought to turn over rapidly (reviewed in Ritchie, 1988) and that glial cells expressing $\mathrm{Na}^{+}$ channels come into close contact with nodes of Ranvier in both the CNS and PNS (Black et al., 1989; Suarez and Raff, 1989) favor this hypothesis. That glial $\mathrm{Na}^{+}$channels have properties different from those of neuronal channels (Barres et al., 1989; Howe and Ritchie, 1990) argues against this hypothesis. Since $\mathrm{O} 2 \mathrm{~A}$ progenitor cells persist in adult animals and have the neuronal form of the $\mathrm{Na}^{+}$channel, they are a potential source of neuronal $\mathrm{Na}^{+}$channel proteins (Table 2; ffrench-Constant and Raff, 1986); it is not known, however, whether the processes of $\mathrm{O} 2 \mathrm{~A}$ progenitors do contact nodes of Ranvier.

Although once thought to be ubiquitously present in glial cells and to underlie their resting potential, voltage-independent "leakage" $\mathrm{K}^{+}$channels have not, in fact, been found in them thus far. A leakage $\mathrm{K}^{+}$conductance has not been observed in optic nerve astrocytes or oligodendrocytes, nor in Müller cells or Schwann cells (Newman, 1989; Barres et al., 1990b,c; Wilson and Chiu, 1990). In optic nerve glia, for instance, blockade of voltage-dependent conductances with specific ion channel blockers obliterates virtually all membrane currents, indicating that the resting $\mathrm{K}^{+}$conductance of glia cannot be accounted for by voltage-independent leakage channels (Barres et al., 1990b,c). Thus, it seems likely that voltage-dependent $\mathrm{K}^{+}$channels underlie the resting conductance of glial cells. In particular, inwardly rectifying $\mathrm{K}^{+}$channels, channels that are specialized to favor inward rather than outward movement of $\mathrm{K}^{+}$ions, have now been described in all of the main types of glial cells and seem to be responsible for the resting conductance in many, and perhaps all, glial cells. In addition, it has been suggested that ligand-gated channels might contribute to the resting conductance of some glial cell types (Clark and Mobbs, 1992).

\section{Neurotransmitter receptors of glial cells}

Glial cells in culture respond to a variety of neurotransmitters with changes in membrane potential (reviewed by Bevan, 1990). Until recently, it was not clear whether any of these changes are mediated by opening of ligand-gated ion channels, or only by the activation of electrogenic neurotransmitter uptake processes and by modulation of voltage-dependent channels known to be present in glia. New studies have demonstrated that most, if not all, glial cells in vitro and in vivo express one or more types of ligand-gated channels.

Glutamate- and GABA-gated ion channels are present in astrocytes in vitro (Bormann and Kettenmann, 1988; Sontheimer et al., 1988; Usowicz et al., 1989; Cull-Candy and Wyllie, 1991). Detailed single-channel characterizations of GABA-gated $\mathrm{Cl}^{-}$ channels in cortical type 1-like astrocytes (Bormann and Kettenmann, 1988), and of glutamate-gated cation channels in O2A progenitors and type 2 astrocytes (Usowicz et al., 1989), show that these channels are similar to their neuronal counterparts.

Wyllie et al. (1991) have carefully dissected the components of glutamate-gated currents in both type 1 and type 2 astrocytes in short-term culture. While glutamate depolarizes both type 1 and type 2 astrocytes, it does so by different mechanisms. They found that glutamate induces large whole-cell currents in type 1 astrocytes that are mediated entirely by electrogenic uptake of glutamate; do not reverse; are associated with an increase in current noise; are elicited also by aspartate but not by quisqualate, kainate or NMDA; and are inhibited by replacement of extracellular $\mathrm{Na}^{+}$by $\mathrm{Li}^{+}$(which can pass through the glutamate-gated channels of type 2 astrocytes). In contrast, type 2 astrocytes have glutamate-gated currents that reverse direction at $0 \mathrm{mV}$, are associated with a noise increase, and are blocked by non-NMDA antagonists. Iontophoretic mapping showed that quisqualate and kainate sensitivity is distributed over the somata, as well as along the entire length of their processes. A similar glutamate-activated response develops in type 1 astrocytes after 1 week of culture (also see Jensen and Chiu, 1991), but it is unclear whether this change is mediated by an intrinsic 
Table 2. Properties of glial and neuronal sodium channels

\begin{tabular}{|c|c|c|}
\hline & Glial & Neuronal \\
\hline \multicolumn{3}{|l|}{ Whole-cell currents } \\
\hline Activation $(\mathrm{mV})$ & -40 & -30 \\
\hline Half inactivation (mV) & -80 & -55 \\
\hline \multicolumn{3}{|l|}{ Decay time constant $\left(T_{h}\right.$, msec $)$} \\
\hline$-30 \mathrm{mV}$ & 4.4 & 1.8 \\
\hline $0 \mathrm{~m} \varphi$ & 1.3 & 0.5 \\
\hline $\mathrm{TTX} \mathrm{IC}_{50}(\mathrm{nM})$ & 2.8 & 2.6 \\
\hline \multicolumn{3}{|l|}{ Single-channel currents } \\
\hline Conductance $(\mathrm{pS})$ & 20 & 20 \\
\hline Activation (first latency time) & Slow & Fast \\
\hline Voltage dependent? & Yes & Yes \\
\hline Inactivation (open time) & Slow & Fast \\
\hline Voltage dependent? & No & No \\
\hline \multirow[t]{4}{*}{ Cell type distribution } & Type 1 astrocytes & Retinal ganglion cells \\
\hline & Cortical astrocytes & Cortical motor neurons \\
\hline & Ependymal cells & O2A progenitor cells \\
\hline & Type 2 astrocytes & Type 2 astrocytes \\
\hline
\end{tabular}

Data are summarized from Barres et al. (1989). The glial and neuronal forms of the sodium channel both have a strongly voltage-dependent activation but a voltage-insensitive inactivation, identical TTX sensitivity and single-channel conductance, but the glial channel has a more negative voltage dependence and slower kinetics. The activation voltage is the test potential at which $5 \%$ of the peak inward sodium current is elicited. The half-inactivation voltage is the prepulse potential that inactivates half of the peak inward sodium current. The $\mathrm{TTX} \mathrm{IC}_{50}$ is the concentration that reduces the peak inward current by half.

maturation program or is induced by extrinsic changes occurring over time.

Glutamate- and GABA-gated channels are also present in glial cells in vivo. GABA-gated $\mathrm{Cl}^{-}$currents are found in most Müller cells in retinal slices (Malchow et al., 1989) and in astrocytes in hippocampal slices (MacVicar et al., 1989). Non-NMDA glutamate-gated cation channels are found in all acutely isolated O2A progenitors prior to culture (Barres et al., 1990b). Glutamate-gated channels do not appear to be present in acutely isolated optic nerve astrocytes in vivo: optic nerve type 1 astrocytes lack glutamate-gated channels, and the small numbers of type 2 astrocytes in vivo have so far precluded a similar electrophysiological analysis (Barres et al., 1990c).

Glutamate- and GABA-gated channels have, however, been observed in other mammalian astrocytes in acute preparations. Clark and Mobbs (1991) used whole-mount preparations of the rabbit retina to study astrocytes on the vitreal surface of the retina visual streak. The cells were identified as astrocytes by Lucifer yellow dye filling during the patch-clamp recording. All of the cells studied contained glial fibrillary acidic protein, an intermediate filament protein found in many astrocytes, and had end feet that contacted blood vessels. Eighty-nine percent of the cells had non-NMDA glutamate-activated currents and $100 \%$ had GABA-activated currents. Both currents are mediated by ligand-gated channels with properties similar to those previously reported for neurons. In contrast to many astrocyte types previously studied in vitro, the retinal astrocytes in situ appear to lack both electrogenic glutamate and GABA uptake mechanisms.

In addition to neurotransmitter-gated channels, astrocytes in culturc also cxpress many neurotransmitter receptors that activate intracellular signaling systems. For example, they mediate increases of intracellular concentrations of diacylglycerol, inositol triphosphate, $\mathrm{Ca}^{2+}$, cAMP, and cGMP(Murphy and Pearce,
1987; Bevan, 1990), which can, in turn, modulate the activity of ion channels and enzymes. The presence of these receptors seems to depend on the specific brain region from which the glial cells were isolated (Cholewinski and Wilkin, 1988; Cholewinski et al., 1988).

\section{Influence of the presence of neurons on glial properties}

Because glial cells are difficult to identify and study in situ, most of our knowledge of their properties comes from in vitro studies. Cortical astrocytes have been especially widely used, largely because they are easily prepared in relatively pure form (McCarthy and deVellis, 1980). The astrocytes in these cultures are generally referred to as cortical type 1-like astrocytes because they morphologically resemble type 1 astrocytes in cultures derived from optic nerve and other central white matter. Much of our knowledge of glial ion transport, $\mathrm{pH}$ regulation, neurotransmitter uptake, energy metabolism, and responses to neurotransmitters derives from studies of cortical astrocytes in such neuron-free cultures.

There are two reservations, however, about conclusions drawn from studies of astrocytes in culture. First, it is unclear whether the astrocytes that survive in cultures derived from brain include protoplasmic astrocytes, which are the main type of astrocyte found in gray matter. It is likely that fibrous astrocytes, the main type of white matter astrocyte, survive, since optic nerve astrocytes survive in culture and have a similar morphology. It is still uncertain whether the protoplasmic and fibrous phenotypes reflect intrinsic or environmental differences of astrocytes.

Second, glial cells might behave differently in culture from glial cells in situ. In culture, type 1 astrocytes lack processes; in situ they bear many processes. This difference appcars to bc accounted for by an influence in situ of neurons on the astrocytes: addition of neurons to astrocyte cultures induces the formation of processes by the astrocytes (Hatten, 1985; Miller et al., 1989b). 
Several recent studies indicate that membrane properties of glia differ in culture and in situ as well. Optic nerve type 1 astrocytes in culture express fewer types of ion channels than type 1 astrocytes in situ (Table 1; Barres et al., 1990c). This difference is also accounted for by the absence of neurons in culture: nerve transection causes the astrocytes in situ to revert to the simpler channel phenotype, and addition of neurons to the cultures induces the more complex phenotype (see also Minturn et al., $1990 \mathrm{a}, \mathrm{b})$. The neurons specifically affect type 1 astrocytes; the channel phenotypes of the other optic nerve glial cell types are not affected.

The influence of neurons on membrane properties of glial cells has also been demonstrated in scveral other glial cell types. Myelinating Schwann cells lack $\mathrm{Na}^{+}$channels in situ but have them in culture or after nerve transection (Chiu, 1987, 1988; but see Howe and Ritchie, 1990); nonmyelinating Schwann cells, in contrast, have $\mathrm{Na}^{+}$channels in situ but lose them after nerve transection (Chiu, 1988). Cortical type 1-like astrocytes lack $\mathrm{Ca}^{2+}$ channels in neuron-free cultures but have them upon addition of neurons (Corvalan et al., 1990). Co-culture with neurons can also influence the presence of neurotransmitter receptors (Maderspach and Fajszi, 1983) and neurotransmitterdegradative enzymes (Westergaard et al., 1991) in glial cells.

The influence of neurons on glial ion channel expression suggests that the expression or function of other membrane proteins, such as neurotransmitter carriers and ion transporters, could also be regulated by neurons. For example, $\mathrm{Cl}^{-}$is actively taken up by astrocytes in culture (Kettenmann et al., 1987), but is passively distributed across the ccll membranc in situ (Ballanyi et al., 1987), suggesting that the expression of $\mathrm{Cl}^{-}$transport proteins in astrocytes differs in vitro and in vivo. Thus, in the absence of data supporting their physiological relevance, the results of studies of astrocyte properties in culture should be cautiously interpreted.

\section{Novel neuronal-glial signaling mechanisms}

The presence of neurotransmitter receptors on glia suggests that signaling via neurotransmitters between neurons and glia might occur. Two examples of such signaling from neuron to glia have been reported.

Squid giant axons have been found to signal their Schwann cells (Lieberman et al., 1989; Lieberman, 1991). During stimulation of the squid giant axon, their enveloping Schwann cells first depolarize and then rapidly hyperpolarize. When glutamatc, a likely neurotransmitter at the neuromuscular junction of squid, is applied to Schwann cells, it triggers the same sequence of depolarization and hyperpolarization; the glutamate is thought to act indirectly, by stimulating the Schwann cells to release ACh, which mediates an autocrine hyperpolarization. As glutamate is found in high concentration (25 mM) in the axoplasm of the squid giant axon and both the nerve-impulse-induced and glutamate-induced changes of Schwann cell potential are blocked by 2-amino-4-phosphonobutyric acid, it seems likely that, during stimulation, glutamate is released from the axon onto the Schwann cells. This nonsynaptic transmitter release could be mediated by the reversed operation of glutamate carriers previously demonstrated to be present in the squid giant axon (Baker and Potashner, 1971, 1973; Szatkowski et al., 1990; see below). It has been suggested that this signaling mechanism in squid giant axons may be part of a $\mathrm{K}^{+}$regulatory mechanism (Lieberman et al., 1989), and this is supported by the finding that elevations of extracellular $\mathrm{K}^{+}$enhance carrier-mediated glutamate release (Szatkowski et al., 1990; see below).

It is possible that neuron to glial signaling processes, analogous to those occurring in the squid giant axon, occur in the mammalian CNS. Impulse-mediated release of preloaded ${ }^{3} \mathrm{H}-$ glutamate from nonsynaptic regions of the optic nerve has been reported (Wheeler et al., 1966; see also Weinreich and Hammerschlag, 1975). Glutamate is likely to be present in optic nerve axons, since it is thought to be used as a transmitter by most retinal ganglion cells. Several types of glutamate receptors are found on optic nerve glial cells: metabotropic glutamate receptors (Sugiyama et al., 1987) are found on type 1 astrocytes (Pcarcc ct al., 1986; Corncll-Bell ct al., 1990a; Jensen and Chiu, 1990, 1991), and non-NMDA ionotropic glutamate receptors are found on $\mathrm{O} 2 \mathrm{~A}$ progenitors and type 2 astrocytes (Usowicz et al., 1989). Thus, although direct evidence is lacking, it is plausible that neuron-to-glia signaling occurs in white matter.

A second example of neuron to glial signaling mediated by neurotransmitters occurs in mammalian brain slices (Dani et al., 1990a,b). Cornell-Bell et al. (1990a) described an oscillatory increase in cytosolic free $\mathrm{Ca}^{2+}$ in hippocampal astrocytes in culture in response to glutamate and non-NMDA glutamate analogs. These glutamate-induced increases in $\mathrm{Ca}^{2+}$ concentration are propagated as waves, both within the cytoplasm of individual astrocytes and between adjacent astrocytes in confluent cultures. These observations raised the question of whether neurons could elicit such $\mathrm{Ca}^{2+}$ waves in astrocytes. Two lines of experimentation suggest that the answer is "yes." First, in co-cultures of hippocampal ncurons and astrocytes, NMDA triggers $\mathrm{Ca}^{2+}$ waves in the astrocytes. Since the astrocytes are believed to express only non-NMDA receptors, the $\mathrm{Ca}^{2+}$ waves are most likely induced by an NMDA-evoked glutamate release from the neurons. Moreover, the astrocyte waves can be elicited in an organotypic hippocampal slice preparation, either by the application of NMDA or by the stimulation of the afferent mossy fiber pathway (Dani et al., 1990a,b). A laser confocal microscope and the $\mathrm{Ca}^{2+}$ indicator dye fluo-3 were used to follow the waves along astrocytes in the stratum lucidum, and the slices were stained with anti-GFAP antibodies to verify the astrocytic localization. The $\mathrm{Ca}^{2+}$ concentration in the astrocytes oscillated at a frequency of about $1-20 / \mathrm{sec}$ and the $\mathrm{Ca}^{2+}$ waves propagated at a velocity of about $20 \mu \mathrm{m} / \mathrm{sec}$. As would be expected if neurons were involved in the signaling pathway, TTX blocked the glial $\mathrm{Ca}^{2+}$ oscillations. The $\mathrm{Ca}^{2+}$ waves could be elicited by weak stimuli, which did not exceed those occurring normally in vivo. These observations suggest that astrocyte networks might be involved in long-distance signaling within the brain. The possible functional significance of such signaling is not known, but is discussed further below.

Another possible pathway of neuron to glial signaling, mediated by nitric oxide (NO), has recently been suggested (Garthwaite et al., 1988). Also known as endothelial-derived relaxing factor, NO is synthesized by a variety of cell types, in addition to endothelial cells (for a recent review, see Snyder and Bredt, 1991). It stimulates an increase in cytoplasmic cGMP by activating a soluble guanylate cyclase. Recently, it has been found that glutamate induces the formation of NO by some neurons (Bredt and Snyder, 1989; Garthwaite et al., 1989a,b). NO is synthesized from L-arginine by NO synthase, which has been immunocytochemically localized in the brain to certain neurons and their axons (Knowles et al., 1989; Bredt et al., 1990). The NO synthase is activated by a glutamate-induced increase in 
cytoplasmic $\mathrm{Ca}^{2+}$; the $\mathrm{Ca}^{2+}$ binds to calmodulin, which then activates the NO synthase (Bredt et al., 1990). Since nitric oxide is membrane soluble, it is thought to diffuse out of the neuron and activate guanylate cyclase in neighboring neurons and glia (Garthwaite et al., 1988). Astrocytes contain soluble guanylate cyclase and respond to NO with an increase in cGMP (ChanPalay and Palay, 1979; Nakane et al., 1983; deVente et al., 1989; Ishizaki et al., 1991). But how does an increase in intracellular cGMP affect the function of astrocytes? One possibility is that cGMP decreases their coupling by gap junctions, as occurs in retinal horizontal cells (DeVries and Schwartz, 1989). Another is that cGMP modulates their resting conductance, as it does in heart cells, where it decreases an inwardly rectifying $\mathrm{K}^{+}$conductance (Wahler and Sperelakis, 1988; see also Krnjevic and vanMeter, 1976).

\section{Synthesis and release of neurotransmitters by glial cells}

Can glial cells signal neurons? Glial cells synthesize and, in some cases, release neurotransmitters. Schwann cells of the squid giant axon normally synthesize and release ACh (Heumann et al., 1981). Frog Schwann cells covering denervated muscle end plates release ACh (Birks et al., 1960), and when co-cultured with myotubes, rat Schwann cells express ChAT and synthesize ACh (Brockes, 1984).

Suggestive evidence for the release of other neurotransmitters by glial cells comes from a large number of experiments in which glial cells in vitro or in situ release preloaded neurotransmitters, such as ${ }^{3} \mathrm{H}-\mathrm{GABA}$, in response to depolarizing stimuli (e.g., Minchen and Iverson, 1974; Gallo et al., 1986). In most cases, however, there is little evidence that these cells normally synthesize or secrete these transmitters. A variety of neurotransmitters can be detected using immunohistochemistry: homocysteic acid, a glutamate analog, has been localized to glial cells in sections of brain (Cuenod et al., 1990); glutamate-like immunoreactivity has been demonstrated in glial cells ensheathing sensory ganglion cell neurons, and aspartate-like immunoreactivity of glia has been demonstrated in some brainstem glia (Zhang et al., 1990; Kai-kai and Howe, 1991). While these findings are intriguing, it is not clear whether the glial cells synthesize these transmitters for release or, instead, take them up from the extracellular fluid.

Thus, although there is not yet convincing evidence that glial cells in the mammalian CNS or PNS normally synthesize and release neurotransmitters, suggestive observations are accumulating, particularly in the case of the $\mathrm{O} 2 \mathrm{~A}$ glial progenitor cell. O2A progenitor cells, both in culture and after acute isolation, have GABA-like immunoreactivity. Moreover, GABA can be detected using HPLC in O2A cells cultured in medium lacking any source of GABA (Barres et al., 1990b). Although glutamic acid decarboxylase is not detectable in them, $\mathrm{O} 2 \mathrm{~A}$ cells appear to synthesize GABA via an alternative synthetic pathway, which uses putrescine rather than glutamate as a precursor. When putrescine is omitted from the culture medium, GABA can no longer be detected in $\mathrm{O} 2 \mathrm{~A}$ cells by immunocytochemistry or by HPLC. It is not known whether O2A cells can normally secrete the GABA they synthesize, although they can release preloaded ${ }^{3} \mathrm{H}-\mathrm{GABA}$, taken up by an $\mathrm{Na}^{+}$-dependent GABA carrier, in response to stimulation of their non-NMDA glutamate receptors (Gallo et al., 1991). As the $\mathrm{Na}^{+}$-dependent GABA carrier appears to be able to mediate GABA release (Schwartz, 1987; see also below), it is plausible that O2A cells might release GABA in situ in response to glutamate-mediated depolarization.
Glial cells do not contain synaptic vesicles, but it has been suggested that they might release neurotransmitters by $\mathrm{Ca}^{2+}$ independent carrier mechanisms. A recurrent suggestion is that the release might be mediated by the reverse operation of electrogenic neurotransmitter carrier proteins, which normally function to take up neurotransmitters. Although these carrier proteins can be induced to release transmitter by "reversed uptake" in special experimental conditions (e.g., Schwartz, 1987), it has not been clear whether such reversed operation of an electrogenic carrier could mediate neurotransmitter release under physiological conditions.

Evidence that glutamate release by reversed uptake might occur under physiological conditions comes from studies of salamander Müller cells, in which uptake of glutamate by these cells is activated by raising intracellular $\mathrm{K}^{+}$, probably because $\mathrm{K}^{+}$is transported out of the cell while $\mathrm{Na}^{+}$and glutamate are transported in (Barbour et al., 1988). Upon raising intracellular $\mathrm{Na}^{+}$and glutamate, elevation of extracellular $\mathrm{K}^{+}$activated an outward current, reflecting glutamate release (Szatkowski et al., 1990). The stoichiometry of this process appears to amount to the release of one glutamate anion and three $\mathrm{Na}^{+}$ions for every $\mathrm{K}^{+}$ion taken up. Reverse uptake of glutamate could occur in physiological concentrations of intracellular $\mathrm{Na}^{+}$and glutamate. For instance, reversed glutamate uptake could be elicited at a membrane potential of $0 \mathrm{mV}$, with a pipette containing $90 \mathrm{~mm}$ $\mathrm{K}^{+}, 10 \mathrm{mM} \mathrm{Na}{ }^{+}$, and $10 \mathrm{~mm}$ glutamate, at $10 \mathrm{mM} \mathrm{K}^{+}$in the extracellular fluid. Because of the large depolarizations necessary to drive the reversed uptake, however, this mechanism is unlikely to mediate transmitter release from most glial cells, although it could mediate $\mathrm{Ca}^{2+}$-independent release in neurons, axons, and perhaps particular kinds of glia, such as the O2A progenitor cell.

\section{Possible glial functions}

Thus, glial cells, although not excitable and not capable of vesicular neurotransmitter release, have the machinery necessary to respond to and potentially release humoral signals. There is no direct evidence, however, that glial cells in adult mammalian brains are involved in signaling; this lack of evidence might mostly be due to both the experimental difficulty of studying signaling mechanisms other than impulses, and the lack of specific hypotheses to test. Three possible glial functions, requiring neuronal to glial signaling, will be considered: regulation of $\mathrm{K}^{+}$, regulation of the microcirculation, and regulation of synaptic function.

Potassium buffering. During neuronal activity, $\mathrm{K}^{+}$concentrations increase in the relatively small extracellular space (Orkand et al., 1966). A sufficient increase in $\mathrm{K}^{+}$could cause neuronal depolarization and be detrimental to continued neuronal signaling. Thus, a need for a $\mathrm{K}^{+}$buffering mechanism has been inferred, although it is still unclear where, and to what extent, such a mechanism is required. It was proposed that glial cells regulate $\mathrm{K}^{+}$, since their $\mathrm{K}^{+}$-selective membranes act as $\mathrm{K}^{+}$electrodes, responding with depolarization to small increases in extracellular $\mathrm{K}^{+}$(Orkand et al., 1966). It now seems likely that glial cells play this role, since an increase in glial intracellular $\mathrm{K}^{+}$during neuronal activity is observed in a variety of preparations (e.g., Coles and Tsacopoulos, 1979; Coles and Orkand, 1983; Ballanyi et al., 1987).

How do glial cells regulate extracellular $\mathrm{K}^{+}$? They could shunt it distally (spatial buffering), or they could store it locally $\left(\mathrm{K}^{+}\right.$ accumulation), or they could do both. How they might shunt it 
distally, using only passive fluxes of ions, was suggested by Orkand et al. (1966): the glial depolarization resulting from a local increase in extracellular $\mathrm{K}^{+}$would produce a spatial gradient of membrane potential along a glial syncytium that would drive a "spatial buffer" current, which would move $\mathrm{K}^{+}$through the glial cell syncytium to a distal region. Spatial buffering would not require any special neuronal to glial signals other than the released $\mathrm{K}^{+}$, since the resting $\mathrm{K}^{+}$conductance of glia is normally large. Such spatial buffer currents through Müller cells have been observed (Karwoski et al., 1989).

Although there is no longer any doubt that spatial buffering does occur, it is not clear whether it is quantitatively sufficient. Indeed, Kuffler and Nicholls (1966) emphasized that further work would be required to determine whether this mechanism could move sufficient amounts of $\mathrm{K}^{+}$to provide effective control of extracellular $\mathrm{K}^{+}$. There are several reasons to suspect that it might not. First, diffuse neuronal activity will tend to abolish the gradient of membrane potential necessary to drive a spatial current. This is particularly problematic in axon tracts (for further discussion, see Barres et al., 1988a, 1990a,c). Second, even if an effective gradient of membrane potential could be generated, the high $\mathrm{K}^{+}$conductance of glial processes implies a short electrical space constant. Thus, the shunted $\mathrm{K}^{+}$will leak out into the extracellular space, dissipating the gradient necessary to drive the spatial buffer current. Adult optic nerve astrocytes have a length constant of less than $100 \mu \mathrm{m}$, substantially less than the length of a typical astrocyte process (Barres ct al., 1990 c).

Do glial cells control extracellular $\mathrm{K}^{+}$by storing it locally? The discovery that the glial resting conductance is inwardly rectifying for $\mathrm{K}^{+}$strongly supports the possibility of local storage, since $\mathrm{K}^{+}$should enter glia more readily than it leaves (Barres et al., 1988a, 1990c). $\mathrm{A} \mathrm{K}^{+}$accumulation mechanism mediated by passive fluxes of $\mathrm{K}^{\prime}, \mathrm{Cl}$, and water (Boyle and Conway, 1941) has recently been suggested for glia (Ranck, 1964; Gray and Ritchie, 1986; Ballanyi et al., 1987; Barres et al., 1988a, 1990c; Coles et al., 1989). Glial cells have been thought to lack $\mathrm{Cl}^{-}$ channels that open near the resting potential. However, a $\mathrm{Cl}^{-}$ conductance has now been described in most glial cell types, including astrocytes, oligodendrocytes, and Schwann cells (Gray et al., 1984; Gray and Ritchie, 1986; Barres et al., 1988a, 1990c). In most cases, these conductances are inactive in the resting cell but become active on excision of a patch of membrane, suggesting that excision reverses a normal inhibitory mechanism. This finding has led to a specific hypothesis of glial $\mathrm{K}^{+}$accumulation triggered by neuronal impulses that would require neuronal to glial signaling: according to this hypothesis, a humoral signal released from neurons activates glial $\mathrm{Cl}^{-}$channels, thus activating $\mathrm{K}^{+}$accumulation by a Boyle and Conway passive flux mechanism (Barres et al., 1988a).

Any $\mathrm{K}^{+}$accumulated by glial cells whose resting conductance is inwardly rectifying for $\mathrm{K}^{+}$can only be slowly released, because, as described for skeletal muscle by Hodgkin and Horowicz (1959), the outward movement of $\mathrm{K}^{+}$is resisted. Thus, this mechanism could account for the previously unexplained slow glial repolarizations observed by Orkand et al. (1966) and Baylor and Nicholls (1969), which lasted many seconds after neuronal impulse activity had ended. The slow repolarization would represent the slow release by glial cells of their accumulatcd $\mathrm{K}^{+}$, $\mathrm{Cl}^{-}$, and water. In this case, the time course of the glial depolarization and repolarization represents, not the time course of $\mathrm{K}^{+}$uptake, but the time of uptake and return to the neuron.
Also, if present, a $\mathrm{Cl}^{-}$conductance may become greater than the $\mathrm{K}^{+}$conductance during repolarization. In this case (because of the inward rectification), glial potential would reflect the chloride equilibrium potential $\left(V_{\mathrm{Cl}}\right)$ and not the potassium equilibrium potential $\left(V_{\mathrm{K}}\right)$, and could not be used to determine the extracellular $\mathrm{K}^{+}$concentration.

Although the inwardly rectifying nature of the $\mathrm{K}^{+}$resting conductance of glia has only recently been found, it was predicted more than 25 years ago by the work of Ranck (1963, 1964). Depending entirely on specific impedance measurements of the rabbit cerebral cortex, he found that his data could be explained by postulating only two populations of cells: one with a relatively high membrane resistance, which he assumed to be neurons, and another with a low membrane resistance, which he assumed to be glia. On the basis of this simple model, he deduced from his data that neurons form $40-50 \%$ of the volume of the cortex, neuroglia cells about 35-56\%, and the total interstitial space about $2-15 \%$. The electrical length constant of the cortical glial cells was no more than $15 \mu \mathrm{m}$, and possibly less than $1 \mu \mathrm{m}$. By studying the specific impedance of rabbit cerebral cortex during spreading depression, a pathological condition accompanied by large elevations of extracellular $\mathrm{K}^{+}$, he observed that the permeability of astrocytes decreased. Thus, he deduced that the neuroglia had an inwardly rectifying $\mathrm{K}^{+}$conductance, which might help the cells to buffer the interstitial space against rises in $\mathrm{K}^{+}$.

The evidence that glia buffer $\mathrm{K}^{+}$in the interstitial space by accumulation has become increasingly convincing. The spatial buffering and $\mathrm{K}^{+}$accumulation hypotheses entail different predictions, and in most cases where these have been tested, results indicate that glial cells accumulate $\mathrm{K}^{+}$during neuronal activity (Table 3; for further discussion, see Barres et al., 1990a). Whether this glial $\mathrm{K}^{+}$accumulation is in fact triggered by an impulsemediated neuronal signal other than elevated $\mathrm{K}^{+}$remains to be determined. The central prediction of such an impulse-triggered $\mathrm{K}^{+}$accumulation mechanism is that an extracellular $\mathrm{K}^{+}$elevation will not be rapidly cleared in the absence of impulse activity.

In summary, a possible function of neuron to glia signaling might be to activate an impulse-triggered $\mathrm{K}^{+}$accumulation mechanism in astrocytes, oligodendrocytes, and Schwann cells.

Blood flow. Astrocyte end feet contact capillaries and arterioles. The end feet are separated from the endothelial cells by a basal lamina (Petcrs ct al., 1976). The astrocytcs are thought to induce endothelial cells to form a blood-brain barrier (Janzer and Raff, 1987), and it has been suggested that they might regulate blood flow through the microcirculation (e.g., Newman et al., 1984; Clark and Mobbs, 1992), by mediating the local increases in blood flow observed after regional increases in neuronal activity. As the same astrocyte can contact both axons and blood vessels (Peters et al., 1976; Suarez and Raff, 1989), a neuron to astrocyte to blood vessel signaling mechanism could operate to regulate blood flow.

A candidate molecule for such a glial-to-endothelial cell signal is NO. Astrocytes have been reported to synthesize and release an NO-like substance (Murphy et al., 1990), although NO synthase has not yet been detected in glia (Bredt et al., 1990). L-Arginine, the precursor of $\mathrm{NO}$, is predominantly stored in astrocytes in the CNS, particularly astrocytes contacting blood vessels (Aoki et al., 1991). Since NO synthase is activated by $\mathrm{Ca}^{2+}$, an interesting possibility is that the neuronally triggered waves of $\mathrm{Ca}^{2+}$ passing through astrocyte syncytia studied by Dani et al. (1990a,b) might function to regulate blood flow. 


\begin{tabular}{|c|c|c|c|c|}
\hline Prediction & $\begin{array}{l}\text { Spatial } \\
\text { buffer- } \\
\text { ing }\end{array}$ & $\begin{array}{l}\text { Potas- } \\
\text { sium } \\
\text { accumu- } \\
\text { lation }\end{array}$ & $\begin{array}{l}\text { Obser- } \\
\text { vation }\end{array}$ & References \\
\hline \multicolumn{5}{|l|}{ Elevation of glial: } \\
\hline $\mathbf{K}^{+}$ & Yes & Yes & Yes & $\begin{array}{l}\text { Coles and Tsacopoulos (1979) } \\
\text { Ballanyi et al. (1987) } \\
\text { Coles et al. (1989) }\end{array}$ \\
\hline $\mathrm{Cl}^{-}$ & No & Yes & Yes & $\begin{array}{l}\text { Ballanyi et al. (1987) } \\
\text { Coles et al. (1989) }\end{array}$ \\
\hline Decrease of extracellular space & No & Yes & Yes & $\begin{array}{l}\text { Dietzel et al. (1982) } \\
\text { Ransom et al. (1985) }\end{array}$ \\
\hline Swelling of glia & No & Yes & Yes & $\begin{array}{l}\text { Wurtz and Ellisman (1986) } \\
\text { Wuttke (1990) }\end{array}$ \\
\hline $\mathrm{Cl}^{-}$-free solutions impair buffering & No & Yes & Yes & Coles et al. (1989) \\
\hline
\end{tabular}

Tabulation of the effects of neuronal impulse activity on glial intracellular potassium concentration ( $\left.\mathrm{K}^{+}\right)$, glial intracellular chloride concentration $\left(\mathrm{Cl}_{i}{ }_{i}\right)$, volume of the extracellular space, volume of glial cells, and of whether extracellular chloride depletion impairs potassium buffering. The spatial buffering and glial potassium accumulation hypotheses lead to predictions. Some of these predictions have recently been tested; these observations are summarized on the right side of the table. In addition to the differing predicted shifts of ion distributions, volume shifts are also predicted by a glial potassium accumulation, since water must accompany the accumulated $\mathrm{K}^{+}$and $\mathrm{Cl}^{-}$ions. The observations suggest that potassium accumulation by glial cells occurs during neuronal activity. These observations, however, are also consistent with the simultaneous occurrence of both spatial buffering and potassium accumulation.

Synaptic function. Might neuronal-glial signaling be involved in information processing? Because glial cells lack excitability and do not receive or form synapses, it is clear they cannot participate in local neural circuits in the way that neurons do. CNS synapses are, however, generally encapsulated by glial cell processes (Spacek, 1971; Peters et al., 1976). The close spatial and dynamic relationship of glia and synapses is highlighted by videomicroscopic observations of parasympathetic ganglion synapses formed over several months (Pomeroy and Purves, 1988). Preganglionic nerve terminals normally synapse on salivary duct ganglion neuronal fingers that are intertwined with glial processes. These terminals gradually change their configuration over weeks (Purves et al., 1987), as do the position and number of glial nuclei associated with identified neurons. Coordination of the synaptic and glial changes apparently occurs because, despite the continuing changes in synaptic configuration, the presynaptic terminals remain near the glial nuclei (Pomeroy and Purves, 1988). Neuronal-glial signaling processes might mediate the formation of such contacts between glial processes and synapses: glutamate, for example, induces a rapid extension of filopodia from the surface of hippocampal astrocytes, and similar filopodia develop when astrocytes are contacted by pyrimadal neuron growth cones (Cornell-Bell et al., 1990b).

The glial cells associated with synapses are thought to takc up transmitters, thereby helping to terminate neurotransmitter action; they are also thought to provide synaptic insulation by preventing neurotransmitter spillover to nearby synapses (Ramon y Cajal, 1909; Peters et al., 1976). Glial cells at synapses might also have additional functions. Although little is known about the properties of the protoplasmic astrocytes in gray matter that encapsulate synapses, glia might modify glutamatergic transmission at excitatory synapses, in several possible ways.

First, glial cells can help to regulate ion concentrations in small synaptic spaces and thereby regulate synaptic transmission. For example, $\mathrm{Ca}^{2+}$ accumulation by glia would lower $\mathrm{Ca}^{2+}$ in the synaptic cleft, thus reducing $\mathrm{Ca}^{2+}$-dependent transmitter release.
Release of $\mathrm{K}^{+}$from glia might depolarize nerve terminals, altering both spontaneous and impulse-mediate presynaptic release (see discussion in Kuffler, 1967). Release of $\mathrm{K}^{+}$would also inhibit presynaptic reuptake of glutamate (Szatkowski et al., 1990). Glial cells might regulate extracellular bicarbonate, which can interact with certain glutamate agonists to enhance receptor activation (Weiss and Choi, 1988; Weiss et al., 1989).

Second, alterations in glial glutamate uptake would alter glutamate concentrations in the synaptic cleft. Since glutamate uptake into glial cells is electrogenic, large alterations of uptake can be caused by small alterations of glia membrane potential (Schwartz and Tachibana, 1990), which would be caused by activation of glial neurotransmitter receptors by substances released from neurons. For instance, neuronal release of arachidonic acid (Dumuis et al., 1990) should decrease glial glutamate uplake, since micromolar concentrations of arachidonic acid produce a sustained suppression of the electrogenic glutamate carrier (Barbour et al., 1989). Decreases in glial glutamate uptake could increase baseline glutamate concentrations in the synaptic cleft, causing glutamate receptor desensitization, which could decrease synaptic efficacy under normal circumstances (Trussel and Fischbach, 1989) or, in contrast, might prolong glutamate transmission (Barbour et al., 1989).

Lastly, release of small molecules synthesized by glia might also influence the postsynaptic response to neurotransmitters. These molecules might include the glutamate potentiator glycine (Johnson and Ascher, 1987), the glutamate agonists quinolinic acid (Kohler et al., 1990; Poston et al., 1990) and homocysteic acid (Cuenod et al., 1991), and the glutamate antagonist kynurenic acid (Schwarcz et al., 1990).

Glial cells might even participate in long-term potentiation. They can synthesize and release arachidonic acid (DeGeorge et al., 1986; Murphy et al., 1988; Dumuis et al., 1989; Ishizaki et al., 1989; Moore et al., 1991), which has been shown to induce a long-term, activity-dependent enhancement of synaptic transmission in the hippocampus (Williams et al., 1989). Because glial cells exhibit a high degree of plasticity in response to neu- 
ronal signals, long-term changes in glial cell membrane properties might mediate long-term changes in synaptic function.

\section{Conclusions}

Although glial cells lack excitability, there is increasing evidence that they are actively involved in neuronal-glial signaling processes. It is not clear what functions these signaling processes serve, but they deserve further study. Neurobiologists have wondered for 150 years what glial cells do; to figure it out we need to disturb the behavior of glial cells while they remain intimately associated with their neuronal partners. For the first time, this goal has become realizable at last because, using transgenic knockout methodology, the production of mutant animals that lack particular glial neurotransmitter receptors or other signaling molecules is possible.

\section{References}

Aoki E, Semba R, Mikoshiba K, Kashiwamata S (1991) Predominant localization in glial cells of free L-arginine: immunocytochemical evidence. Brain Res 547:190-192.

Baker PF, Potashner SJ (1971) The dependence of glutamate uptake by crab nerve on external $\mathrm{Na}$ and K. Biochim Biophys Acta 249:616622.

Baker PF, Potashner SJ (1973) Glutamate transport in inverebrate nerve: the relative importance of ions and metabolic energy. J Physiol (Lond) 232:26P-27P.

Ballanyi K, Grafe P, Ten Bruggencate G (1987) Ion activities and potassium uptake mechanisms of glial cells in guinea-pig olfactory cortex slices. J Physiol (Lond) 382:159-174.

Barbour B, Brew H, Attwell D (1988) Electrogenic glutamate uptake in glial cells is activated by intracellular potassium. Nature 335:433435 .

Barbour B, Szatkowski M, Ingledew N, Attwell D (1989) Arachidonic acid induces a prolonged inhibition of glutamate uptake into glial cells. Nature 342:918-920.

Barres BA, Chun LLY, Corey DP (1988a) Ion channel expression by white matter glia: I. Type 2 astrocytes and oligodendrocytes. Glia 1: 10-30.

Barres BA, Silverstein BE, Corey DP, Chun LLY (1988b) Immunological, morphological, and electrophysiological variation among retinal ganglion cells purified by panning. Neuron 1:791-803.

Barres BA, Chun LLY, Corey DP (1989) Glial and neuronal forms of the voltage-dependent sodium channel: characteristics and cell-type distribution. Neuron 2:1375-1388.

Barres BA, Chun LLY, Corey DP (1990a) Ion channels in vertebrate glia. Annu Rev Neurosci 13:441-474.

Barres BA, Koroshetz WJ, Swartz KJ, Chun LLY, Corey DP (1990b) Ion channel expression by white matter glia: the $\mathrm{O} 2 \mathrm{~A}$ glial progenitor cell. Neuron 4:507-524.

Barres BA, Koroshetz WJ, Chun LLY, Corey DP (1990c) Ion channel expression by white matter glia: the type-1 astrocyte. Neuron 5:527544.

Baylor DA, Nicholls JG (1969) Changes in extraccllular potassium concentration produced by neuronal activity in the central nervous system of the leech. J Physiol (Lond) 203:555-569.

Bevan S (1990) Ion channels and neurotransmitter receptors in glia. Semin Neurosci 2:467-481.

Bevan S, Chiu SY, Gray PTA, Ritchie JM (1985) The presence of voltage-gated sodium, potassium and chloride channels in rat cultured astrocytes. Proc R Soc Lond [Biol] 225:299-313.

Birks RI, Katz B, Miledi R (1960) Physiological and structural changes at the amphibian myoneural junction in the course of nerve degeneration. J Physiol (Lond) 150:145-168.

Black JA, Friedman B, Waxman SG, Elmer LW, Angelides KJ (1989) Immuno-ultrastructural localization of sodium channels at nodes of Ranvier and perinodal astrocytes in rat optic nerve. Proc $R$ Soc Lond [Biol] 238:39-51.

Bormann J, Kettenmann H (1988) Patch-clamp study of GABA receptor Cl channels in cultured astrocytes. Proc Natl Acad Sci USA 85:9336-9340.
Boyle PJ, Conway EJ (1941) Potassium accumulation in muscle and associated changes. J Physiol (Lond) 100:1-63.

Bredt DS, Snyder SH (1989) Nitric oxide mediates glutamate-linked enhancement of cGMP levels in the cerebellum. Proc Natl Acad Sci USA 86:9030-9034.

Bredt DS, Hwang PM, Snyder SH (1990) Localization of nitric oxide synthase indicating a neural role for nitric oxide. Nature 347:768770 .

Brockes JP (1984) Assays for cholinergic properties in cultured rat Schwann cells. Proc R Soc Lond [Biol] 222:121-134.

Chan-Palay V, Palay SL (1979) Immunocytochemical localization of cGMP: light and electron microscope evidence for involvement of neuroglia. Proc Natl Acad Sci USA 76:1485-1488.

Chiu SY (1987) Sodium currents in axon-associated Schwann cells from adult rabbits. J Physiol (Lond) 386:181-203.

Chiu SY (1988) Changes in excitable membrane properties in Schwann cells of adult rabbit sciatic nerves following nerve transection. J Physiol (Lond) 396:173-188.

Cholewinski AJ, Wilkin GP (1988) Astrocytes from rat forebrain, cerebellum and spinal cord differ in their responses to vasoactive intestinal peptide. J Neurochem 51:1626-1633.

Cholewinski AJ, Hanley MR, Wilkin GP (1988) A phosphoinositidelinked peptide response in astrocytes: evidence for regional heterogeneity. Neurochem Res 13:389-394.

Clark B, Mobbs P (1992) Transmitter-operated channels in retinal astrocytes studied in vivo by whole-cell patch-clamping. J Neurosci, in press.

Coles JA, Orkand RK (1983) Modification of potassium movement through the retina of the drone (Apis mellifera) by glial uptake. $\mathrm{J}$ Physiol (Lond) 340:157-174.

Coles JA, Tsacopoulos M (1979) Potassium activity in photoreceptors, glial cells and extracellular space in the drone retina: changes during photostimulation. J Physiol (Lond) 290:525-549.

Coles JA, Orkand RK, Yamate CL (1989) Chloride enters glial cells and photoreceptors in response to light stimulation in the retina of the honey bee drone. Glia 2:287-297.

Cornell-Bell AH, Finkbeiner SM, Cooper MS, Smith SJ (1990a) Glutamate induces calcium waves in cultured astrocytes: long range glial signalling. Science 247:470-473.

Cornell-Bell AH, Thomas PG, Smith SJ (1990b) The excitatory neurotransmitter glutamate causes filopodia formation in cultured hippocampal astrocytes. Glia 3:322-334.

Corvalan V, Cole R, DeVellis J, Hagiwara S (1990) Neuronal modulation of calcium channcl activity in culturcd rat astrocytes. Proc Natl Acad Sci USA 87:4345-4348.

Cuenod M, Do KQ, Grandes P, Morino P, Streit P (1990) Localization and release of homocysteic acid, and excitatory sulfur-containing acid. J Histochem Cytochem 38:1713-1715.

Cull-Candy SG, Wyllie DJ (1991) Glutamate receptor channels in mammalian glial cells. Ann NY Acad Sci, in press.

Dani JW, Chernjavsky A, Smith SJ (1990a) Calcium waves propagate through astrocyte networks in developing hippocampal brain slices. Soc Neurosci Abstr 16:970.

Dani JW, Chernjavsky A, Smith SJ (1990b) Calcium waves propagate through astrocyte networks in developing hippocampal brain slices. J Cell Biol 3:389a.

DeGeorge JJ, Morell P, McCarthy KD, Lapetina EG (1986) Adrencrgic and cholincrgic stimulation of arachidonate and phosphatidate metabolism in cultured astroglial cells. Neurochem Res 11:10611071.

deVente J, Bol JG, Steinbusch HW (1989) Localization of cGMP in the cerebellum of the adult rat: an immunohistochemical study. Brain Res 504:332-337.

DeVries SH, Schwartz EA (1989) Modulation of an electrical synapse between solitary pairs of catfish horizontal cells by dopamine and second messengers. J Physiol (Lond) 414:351-375.

Dietzel I, Heinemann U, Hofmeier G, Lux HD (1982) Stimulusinduced changes in extracellular sodium and choride concentration in relation to changes in the size of the extracellular space. Exp Brain Res 46:73-84.

Dumuis A, Pin JP, Oomargari K (1989) ATP-evoked calcium mobilisation and prostanoid release from astrocytes. J Neurochem 52:971977.

Dumuis A, Pin JP, Oomagari K, Sebben M, Bockaert J (1990) Arachidonic acid released from striatal neurons by joint stimulation of 
ionotropic and metabotropic quisqualate receptors. Nature 347:182184.

Feinstein DL, Durand M, Milner RJ (1991) Expression of myosin regulatory light chains in rat brain: characterization of a novel isoform. Mol Brain Res 10:97-105.

ffrench-Constant C, Raff MC (1986) The oligodendrocyte-type 2 astrocyte cell lineage is specialized for myelination. Nature 323:335338.

Frizzel RA, Rechkemmer G, Shoemaker RL (1986) Altered regulation of airway epithelial cell chloride channels in cystic fibrosis. Science 233:558-560.

Gallo V, Suergiu R, Levi G (1986) Kainic acid stimulates GABA release from a subpopulation of cerebellar astrocytes. Eur J Pharmacol 132:319-322.

Gallo V, Patrizio M, Levi G (1991) GABA release triggered by the activation of neuron-like non-NMDA receptors in cultured type-2 astrocytes is carrier mediated. Glia 4:245-255.

Garthwaite J, Charles SL, Chess-Williams R (1988) Endotheliumderived relaxing factor release on activation of NMDA receptors suggests role as intercellular messenger in brain. Nature 336:385-388.

Garthwaite J, Garthwaite G, Palmer RM, Moncada S (1989a) NMDA receptor activation induces nitric oxide synthesis from arginine in rat brain slices. Eur J Pharmacol 172:413-416.

Garthwaite J, Southam E, Anderton M (1989b) A kainate receptor linked to nitric oxide synthesis from arginine. J Neurochem 53:19521954.

Gray PTA, Ritchie JM (1986) A voltage-gated chloride conductance in rat cultured astrocytes. Proc $\mathrm{R}$ Soc Lond [Biol] 228:267-288.

Gray PT, Bevan S, Ritchie JM (1984) High conductance anion-selective channéls in rat cultured Schwann cells. Proc R Soc Lond [Biol] 221:395-409.

Hatten ME (1985) Neuronal regulation of astroglial morphology and proliferation in vitro. J Cell Biol 100:384-396.

Heumann R, Villegas J, Herzfeld DW (1981) Acetylcholine synthesis in the Schwann cell and axon in the giant nerve fiber of the squid. $J$ Neurochem 36:765-768.

Hodgkin AL, Horowicz P (1959) The influence of potassium and chloride ions on the membrane potential of single muscle fibers. J Physiol (Lond) 148:127-160.

Howe JR, Ritchie JM (1990) Sodium currents in Schwann cells from myelinated and non-myelinated nerves of nconatal and adult rabbits. J Physiol (Lond) 425:169-210.

Ishizaki Y, Morita I, Murota S (1989) Arachidonic acid metabolism in cultured astrocytes from rat embryo and in C6 glioma cells. Brain Res 494:138-142.

Ishizaki Y, Morita I, Murota S (1991) Astrocytes are responsive to endothelium-derived relaxing factor (EDRF). Neurosci Lett 125:2930 .

Janzer RC, Raff MC (1987) Astrocytes induce blood-brain barrier properties in endothelial cells. Nature 325:253-257.

Jensen AM, Chiu SY (1990) Fluorescence measurement of changes in intracellular calcium induced by excitatory amino acids in cultured cortical astrocytes. J Neurosci 10:1165-1175.

Jensen AM, Chiu SY (1991) Differential intracellular calcium responses to glutamate in type 1 and type 2 cultured brain astrocytes. J Neurosci 11:1674-1684.

Johnson JW, Ascher P (1987) Glycine potentiates the NMDA response in cultured mouse brain neurons. Nature 325:529-531.

Kai-kai MA, Howe R (1991) Glutamate-immunoreactivity in the trigeminal and dorsal root ganglia, and intraspinal neurons and fibres in the dorsal horn of the rat. Histochem J 23:171-179.

Karwoski CJ, Lu HK, Newman EA (1989) Spatial buffering of lightevoked potassium increases by retinal Müller (glial) cells. Science 244: 505-620.

Kettenmann H, Backus KH, Schachner M (1987) GABA opens chloride channels in cultured astrocytes. Brain Res 404:1-9.

Knowles RG, Palacios M, Palmer RM, Moncada S (1989) Formation of nitric oxide from L-arginine in the central nervous system: a transduction mechanism for the stimulation of the soluble guanylate cyclase. Proc Natl Acad Sci USA 86:5159-5162.

Kohler C, Okuno E, Whetsell WO, Schwarcz R (1990) Immunohistochemical localization of quinolinic acid phophribosyltransferase in the human neostriatum. Soc Neurosci Abstr 16:491.18.

Krnjevic K, VanMeter WG (1976) Cyclic nucleotides in spinal cords. Can J Physiol Pharmacol 54:416-421.
Kuffler SW (1967) Neuroglial cells: physiological properties and a potassium mediated effect of neuronal activity on the glial membrane potential. Proc R Soc Lond [Biol] 168:1-21

Kuffler S, Nicholls JG (1966) The physiology of neuroglial cells. Ergeb Physiol 57:1-90.

Kuffier SW, Nicholls JG, Orkand RK (1966) Physiologic properties of glial cells in the central nervous system of amphibia. J Neurophysiol 29:768-787.

Lieberman EM (1991) Role of glutamate in axon-Schwann cell signaling in the squid. Ann NY Acad Sci, in press.

Lieberman EM, Abbott NJ, Hassan S (1989) Evidence that glutamate mediates axon-Schwann cell signalling in the squid. Glia 2:94-102.

MacVicar BA, Tse FW, Crichton A, Kettenmann H (1989) GABAactivated $\mathrm{Cl}$ channels in astrocytes of hippocampal slices. J Neurosci 9:3577-3583.

Maderspach K, Fajszi C (1983) Development of B-adrenergic receptors and their function in glia-neuron communication in cultured chick brain. Dev Brain Res 6:251-257.

Malchow RP, Qian H, Ripps H (1989) GABA-induced currents of skate Müller (glial) cells are mediated by neuronal-like GABA-A receptors. Proc Natl Acad Sci USA 86:4326-4330.

McCarthy KD, deVellis J (1980) Preparation of separate astroglial and oligodendroglial cell cultures from rat cerebral tissue. J Cell Biol 85 : $890-902$.

Miller RH, Raff MC (1984) Fibrous and protoplasmic astrocytes are biochemically and developmentally distinct. J Neurosci 4:585-592.

Miller RH, ffrench-Constant C, Raff MC (1989a) The macroglial cells of the rat optic nerve. Annu Rev Neurosci 12:517-534.

Miller RH, Fulton BP, Raff MC (1989b) A novel type of glial cel associated with nodes of Ranvier in rat optic nerve. Eur J Neurosci 1:172-180.

Minchen MC, Iverson LL (1974) Release of ${ }^{3} \mathrm{H}-\mathrm{GABA}$ from glial cells in rat dorsal root ganglia. $J$ Neurochem 23:533-540.

Minturn JE, Black JA, Angelides KJ, Waxman SG (1990a) Sodium channel expression detected with antibody 7493 in $\mathrm{A}_{2} \mathrm{~B}_{5}$ positive and $A_{2} B_{5}$ negative astrocytes from rat optic nerve in vitro. Glia 3:358367.

Minturn JE, Black JA, Sontheimer H, Emanuel JR, Ransom BR, Waxman SG (1990b) Voltage-sensitive sodium channels in astrocytes deprived of axonal contact: peptides, mRNAs and sodium current expression. J Ccll Biol 111:2745.

Moore SA, Yoder E, Murphy S, Dutton GR, Spector AA (1991) Astrocytes, not neurons, produce docohexaenoic acid and arachidonic acid. J Neurochem 56:518-524.

Murphy S, Pearce B (1987) Functional receptors for neurotransmitters on astroglial cells. Neuroscience 22:381-394.

Murphy S, Pearce B, Jeremy J, Dandona P (1988) Astrocytes as eicosanoid producing cells. Glia 1:241-245.

Murphy S, Minor RL, Welk G, Harrison DG (1990) Evidence for an astrocyte-derived vasorelaxing factor with properties similar to nitric oxide. J Neurochem 55:349-351.

Nakane M, Ichikawa M, DeGuchi T (1983) Light and electron microscopic demonstration of guanylate cyclase in rat brain. Brain Res 273:9-15.

Newman EA (1989) Inward rectifying potassium channels in retinal glial (Müller) cells. Soc Neurosci Abstr 15

Newman EA, Frambach DA, Odette LL (1984) Control of extracellular potassium levels by retinal glial cell K siphoning. Science 225:1174 1175.

Nowycky MC, Fox AP, Tsien RW (1985) Three types of neuronal calcium channel with different calcium agonist sensitivity. Nature 316:440-443.

Orkand RK, Nicholls JG, Kuffler SW (1966) Effect of nerve impulses on the membrane potential of glial cells in the central nervous system of amphibia. J Neurophysiol 29:788-806.

Pearce B, Albrecht J, Morrow C, Murphy S (1986) Astrocyte glutamate receptor activation promotes inositol phosopholipid turnover and calcium flux. Neurosci Lett 72:335-340.

Peters A, Palay SL, Webster HF (1976) The fine structure of the nervous system: the neurons and supporting cells, pp 233-244. Philadelphia: Saunders.

Pomeroy SL, Purves D (1988) Neuron/glia relationships observed over intervals of several months in living mice. J Cell Biol 107:11671175.

Poston MR, Bailey MS, Schwarcz R, Shipley MT (1990) Metabolic 
enzymes for quinolinic acid have different and functionally significant localizations in the rat main olfactory bulb. Soc Neurosci Abstr 16: 139.14.

Purves D, Voyvodic JT, Magrassi L, Yawo H (1987) Nerve terminal remodelling visualized in living mice by repeated examination of the same neuron. Science 238:1122-1126.

Raff MC, Abney ER, Cohen J, Lindsay R, Noble M (1983a) Two types of astrocytes in cultures of developing rat white matter: differences in morphology, surface gangliosides, and growth characteristics. J Neurosci 3:1289-1300.

Raff MC, Miller RH, Noble M (1983b) A glial progenitor cell that develops in vitro into an astrocyte or an oligodendrocyte depending on culture medium. Nature 303:390-396.

Raff MC, Williams BP, Miller RH (1984) The in vitro differentiation of a bipotential glial progenitor cell. EMBO J 3:1857-1864.

Ramon y Cajal S (1909) Histologie du systeme nerveux de l'homme et des vertebres. Madrid: Instituto Ramon y Cajal.

Ranck JB (1963) Specific impedance of rabbit cerebral cortex. Exp Neurol 7:144-174.

Ranck JB (1964) Specific impedance of cerebral cortex during spreading depression, and an analysis of neuronal, neuroglial, and interstitial contributions. Exp Neurol 9:1-16.

Ransom BR, Yamate CL, Connors BW (1985) Activity-dependent shrinkage of extracellular space in rat optic nerve: a developmental study. J Neurosci 5:532-535.

Ritchie JM (1988) Sodium-channel turnover in rabbit cultured Schwann cells. Proc R Soc Lond [Biol] 233:423-430.

Schwarcz R, Du F, Schmidt W, Okuno E (1990) Preferential astroglial localization of kynurenine aminotransferase in the rat hippocampus. Soc Neurosci Abstr 16:491.17.

Schwartz EA (1987) Depolarization without calcium can release GABA from a retinal neuron. Science 238:350-355.

Schwartz EA, Tachibana M (1990) Electrophysiology of aspartate and sodium cotransport in a glial cell of the salamander retina. J Physiol (Lond) 426:43-80.

Snyder S, Bredt DS (1991) Nitric oxide as a neuronal messenger. Trends Pharmacol Sci 12:125-128.

Sontheimer H, Kettenmann H, Backus KH, Schachner M (1988) Glutamate opens $\mathrm{Na} / \mathrm{K}$ channels in cultured astrocytes. Glia 1:328-336.

Spacek J (1971) Three-dimensional reconstructions of astroglia and oligodendroglia cells. Z Zellforsch 112:430-442.

Suarez I, Raff MC (1989) Subpial and perivascular astrocytes associated with nodes of Ranvier in the rat optic nerve. J Neurocytol 18: $577-582$.
Sugiyama H, Ito I, Hirono C (1987) A new type of glutamate receptor linked to inositol phospholipid metabolism. Nature 325:531-533.

Szatkowski M, Barbour B, Attwell D (1990) Non-vesicular release of glutamate from glial cells by reversed electrogenic glutamate uptake. Nature 348:443-446.

Trussel LO, Fischbach GD (1989) Glutamate receptor desensitization and its role in synaptic transmission. Neuron 3:209-218.

Usowicz MM, Gallo V, Cull-Candy SG (1989) Multiple conductance channels in type- 2 cerebellar astrocytes activated by excitatory amino acids. Nature 339:380-383.

Wahler GM, Sperelakis N (1988) Use of the cell-attached patch clamp technique to examine regulation of single cardiac $\mathrm{K}$ channels by cGMP. Mol Cell Biochem 80:27-35.

Weinreich D, Hammerschlag R (1975) Nerve impulse-enhanced release of amino acids from non-synaptic regions of peripheral and central nerve trunks of bullfrog. Brain Res 84:137-142.

Weiss JH, Choi D (1988) Beta- $N$-methylamino-L-alanine neurotoxicity: requirement for bicarbonate as a cofactor. Science 241:973-975.

Weiss JH, Christine DW, Choi DW (1989) Bicarbonate dependence of glutamate receptor activation by B- $N$-methylamino-L-alanine. Neuron 3:321-326.

Westergaard N, Fosmark H, Schousboe A (1991) Metabolism and release of glutamate in cerebellar granule cells cocultured with astrocytes from cerebellum or cerebral cortex. J Neurochem 56:59-66.

Wheeler DD, Boyarsky LL, Brooks WH (1966) The release of amino acids from nerve during stimulation. $J$ Cell Physiol 67:141-148.

Williams JH, Errington ML, Lynch MA, Bliss TVP (1989) Arachidonic acid induces a long term activity-dependent enhancement of synaptic transmission in the hippocampus. Nature 341:739-742.

Wilson GF, Chiu SY (1990) Potassium channel regulation in Schwann cells during early developmental myelinogenesis. J Neurosci 10:16151625.

Wolswijk G, Noble M (1989) Identification of an adult-specific glial progenitor cell. Development 105:387-400.

Wuttke WA (1990) Mechanism of potassium uptake in neuropile glial cells in the central nervous system of the leech. J Neurophysiol 63: 1089-1097.

Wyllie DJ, Mathie A, Symonds CJ, Cull-Candy SG (1991) Activation of glutamate receptors and glutamate uptake in identified macroglial cells in rat cerebellar cultures. J Physiol (Lond) 432:235-258.

Zhang N, Walberg F, Laake JH, Meldrum BS, Ottersen OP (1990) Aspartate-like and glutamate-like immunoreactivities in the inferior olive and climbing fibre system. Neuroscience 38:61-80. 